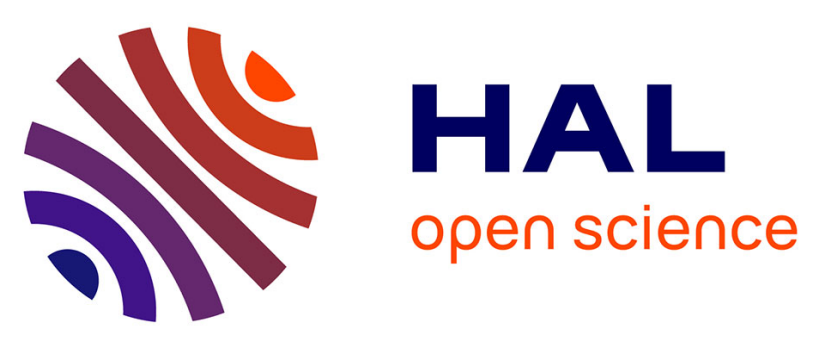

\title{
Short-Term Effects on Diversity and Biomass on Grasslands from Artificial Dykes under Grazing and Mowing Treatments
}

Cannelle Moinardeau, François Mesléard, Hervé Ramone, Thierry Dutoit

\section{- To cite this version:}

Cannelle Moinardeau, François Mesléard, Hervé Ramone, Thierry Dutoit. Short-Term Effects on Diversity and Biomass on Grasslands from Artificial Dykes under Grazing and Mowing Treatments. Environmental Conservation, 2019, Thematic Section: Forests in Flux, 46 (Special issue 2), pp.132139. 10.1017/S0376892918000346 . hal-01936495

\section{HAL Id: hal-01936495 \\ https://hal.science/hal-01936495}

Submitted on 27 Mar 2020

HAL is a multi-disciplinary open access archive for the deposit and dissemination of scientific research documents, whether they are published or not. The documents may come from teaching and research institutions in France or abroad, or from public or private research centers.
L'archive ouverte pluridisciplinaire HAL, est destinée au dépôt et à la diffusion de documents scientifiques de niveau recherche, publiés ou non, émanant des établissements d'enseignement et de recherche français ou étrangers, des laboratoires publics ou privés. 


\title{
Short-Term Effects on Diversity and Biomass on Grasslands from Artificial Dykes under Grazing and Mowing Treatments
}

\author{
Cannelle Moinardeau ${ }^{1}$, François Mesléard ${ }^{1,2}$, Hervé Ramone ${ }^{1}$ and \\ Thierry Dutoit ${ }^{1}$ \\ ${ }^{1}$ Institut Méditerranéen de Biodiversité et Ecologie, UMR CNRS-IRD, Avignon Université, Aix-Marseille Université, \\ IUT d'Avignon, 337 chemin des Meinajariés, Site Agroparc BP 61207, 84911 Avignon, cedex 09, France and \\ ${ }^{2}$ Institut de Recherche de la Tour du Valat, Le Sambuc, 13200 Arles, France
}

\section{Research Paper}

Cite this article: Moinardeau C, Mesléard F, Ramone H, Dutoit T (2018) Short-Term Effects on Diversity and Biomass on Grasslands from Artificial Dykes under Grazing and Mowing Treatments. Environmental Conservation page 1 of 8. doi: $10.1017 /$ S0376892918000346

\section{Keywords}

anthropized ecosystems; cattle grazing; alpha-diversity; beta-diversity; vegetation index

\section{Author for correspondence:}

Cannelle Moinardeau, Email: cannelle. moinardeau@gmail.com

\section{Summary}

Few studies document the impacts of conservation management practices such as extensive grazing or mowing on the new ecosystems created by industrial conversions. In southern France, the Rhône channelling led to the construction of dykes to protect the Tricastin industrialized area from floods. Aiming to control plant dynamics for safety reasons and to favour plant biodiversity, mowing or extensive grazing by cattle were recently tested. Monitoring from both permanent plots and aerial photographs shows that three years of extensive grazing and annual mechanical mowing have modified plant composition, significantly increasing plant species richness, evenness and heterogeneity. The increase in evenness and beta-diversity from grazing was significantly higher than from mowing. Only grazing was able to reduce the height and cover of the dominant tussock perennial grass species (Brachypodium phoenicoides), while increasing bare soil cover and thus the contribution of annual species. The Normalized Difference Vegetation Index (NDVI) obtained through aerial photographic analyses confirmed the correlation between NDVI, aboveground biomass and plant species richness for the grazed site alone, allowing the results obtained from quadrats to be generalized to the scale of the grazed site. On the Rhône's artificial dykes, extensive grazing appears to be a better management tool than mowing to enhance plant biodiversity and meet safety objectives.

\section{Introduction}

Urban and industrial development impact the landscape, constituting a major challenge to biodiversity conservation (Kowarik 2011). Areas housing industrial sites have a different landuse history, which may locally have given rise to 'novel ecosystems' (Hobbs 2006, 2013). Urban and industrial areas are potential reservoirs of biodiversity (Kowarik 2011). Numerous species, including rare species, are able to colonize these urban-industrial sites just as they would in natural conditions (Eversham et al. 1996).

One of the major goals of ecosystem management is to maintain native populations and functions by removing species, disturbances and conditions that lead to degradation (Grumbine 1997). The fact that novel ecosystems, depending on how unique they are, may require the development of new innovative management approaches is a topical issue (Hobbs 2013). Good examples are the many novel ecosystems found along European river valleys heavily modified by human activities such as the construction of dams and dykes (Jensen et al. 2006) since the nineteenth century. Yet conservation of river valleys also needs to focus on the protection or management of the new species-rich habitats created by the construction of artificial dykes and embankments, rather than only on the conservation of relict pieces of ecosystems from the past (Van Diggelen et al. 2006).

Conventional ways of managing biodiversity, such as grazing or mowing, can be efficient tools for these novel ecosystems, as already demonstrated for other semi-natural ecosystems (Carboni et al. 2015). Since the 1970s, the challenge for many of these grasslands has been to institute management practices that will keep them open (Wallis De Vries et al. 2007).

Grazing has been widely promoted as a form of management that can reduce the dominance of some species (Firn et al. 2010), mitigating the effects of increased soil nutrient levels (Weiss 1999). Its extensive use (van Wieren \& Bakker 1998, Marriot et al. 2009) can be attributed to its traditional nature, a form of agricultural management that enhances alphadiversity by promoting species coexistence (Barradas \& Cohen 1994) and beta- and gammadiversity by generating mosaics of habitats (Rosenthal et al. 2012). 
While mowing and grazing are sometimes used together for conservation purposes (Collins et al. 1998, Poschlod \& Wallis De Vries 2002), for the majority of ecosystems, grazing is considered more likely to meet conservation objectives (Tälle et al. 2018). Nevertheless, some grassland ecosystems are exclusively mown (Middleton et al. 2006). This is not only for practical reasons, but also because mowing can sometimes be more efficient in maintaining biodiversity than grazing, depending on the grassland's traditional management history (Stammel et al. 2003). Yet few studies have aimed to compare the two methods of grassland management, and those findings available on their respective advantages are contradictory. A recent review considering 35 studies confirmed that grazing generally has a more positive impact than mowing from a conservation perspective, depending on grassland type (Tälle et al. 2016).

Grazing as a conservation management system has been found to be more relevant after the abandonment of traditional grazing systems than mowing (Tälle et al. 2016). The regular removal of biomass by grazing might partially explain the advantage of grazing in rich or fertilized grasslands, ensuring continuous exportation during the grazing season of mineral elements, as well as indirectly providing continuous control of competition (Hautier et al. 2009). Grazing also promotes greater species richness by creating bare patches due to trampling, by exerting varying degrees of grazing pressure on micro-sites and by dispersing seeds (Cousens et al. 2008). Grazers, in particular horses and sheep, are highly selective due to their higher herbage intake (Duncan 1992), whereas mowing has a more uniform effect, which could explain the greater evenness often observed after mowing than after grazing (Tälle et al. 2016). However, stocking density and grazing regime are two major factors that, by controlling competition and vegetation cover, directly or indirectly drive richness and evenness (Rosenthal et al. 2012). Tälle et al. (2016) concluded that, in many cases, grazing is more beneficial in terms of biodiversity, but that the difference is small.

While numerous studies have examined how grazing or mowing can enhance the conservation value of natural and semi-natural habitats (Rosenthal et al. 2012, Tälle et al. 2016), few have investigated the relevance of these management tools on recently developed ecosystems in an artificial context where the vegetation structure is managed primarily to meet strict safety criteria. Moreover, we wanted to test recent tools such as the vegetation index obtained from remote sensing because these are increasingly being used for conservation purposes and to complement field methods (Pettorelli et al. 2011) through their application at broader scales than botanical inventories conducted on permanent plots. In this three-year study (20142016), we therefore examined the respective impacts of a lowintensity cattle grazing regime and a $1 \mathrm{cut}^{\mathrm{year}}{ }^{-1}$ mowing regime on the spontaneous herbaceous vegetation of artificial dykes located in the Lower Rhône valley (south-eastern France), in the industrial area of the Tricastin nuclear power station. We addressed possible year effects during the three-year survey in order to separate long-term effects of treatments from interannual variation due to potential changes of climatic conditions between years and their likely impacts on vegetation even if the number of cattle was conserved throughout the survey period. We also addressed the potential impacts of abiotic soil characteristics that could also explain differences between recently managed sites (1999 and 2012) and the control site that had not been managed since 1954 .
We addressed the following questions: (1) How do lowstocking density grazing and 1 cut year ${ }^{-1}$ mowing modify the species richness (alpha-diversity), evenness and heterogeneity (beta-diversity) of the herbaceous plant communities of dykes compared to the absence of management? (2) Do abiotic factors such as soil characteristics help explain differences between the managed and control sites? (3) Is the Normalized Difference Vegetation Index (NDVI) a good estimator of biomass, is it indirectly related to species richness obtained from field methods and could it be used by conservation managers at the scale of the sites?

\section{Methods}

\section{Study Site}

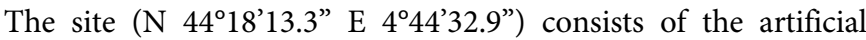
dykes of the dam and the hydro-electric power station of Donzère-Mondragon, located $180 \mathrm{~km}$ south of Lyon and $55 \mathrm{~km}$ north of Avignon in the lower course of the Rhône (Fig. 1). The local climate is Mediterranean, with two main peaks of rainfall (yearly mean: $500-700 \mathrm{~mm}$ ), one in autumn and a lesser one in spring.

Over the last 30 years, the mean annual temperature has been $14^{\circ} \mathrm{C}$ with a total rainfall of $700.9 \mathrm{~mm}$ year $^{-1}$. We recorded only minor divergences from this during the three study years (2014-2016): mean annual temperature varied from 14.7 to $14.9^{\circ}$ $\mathrm{C}$ and total annual rainfall varied from 620 to $696 \mathrm{~mm}$ (Table 1).

The floodway of Donzère-Mondragon was built between 1948 and 1952 and has been managed ever since by the Compagnie Nationale du Rhône (CNR). The dykes studied were built with millions of tonnes of alluvial sediments extracted from digging the canal in the alluvial plain of Tricastin (Fig. 1).

In 1954, a nature reserve covering a band $28 \mathrm{~km}$ long (1500 ha) was created along the dyke to favour game species and to enhance

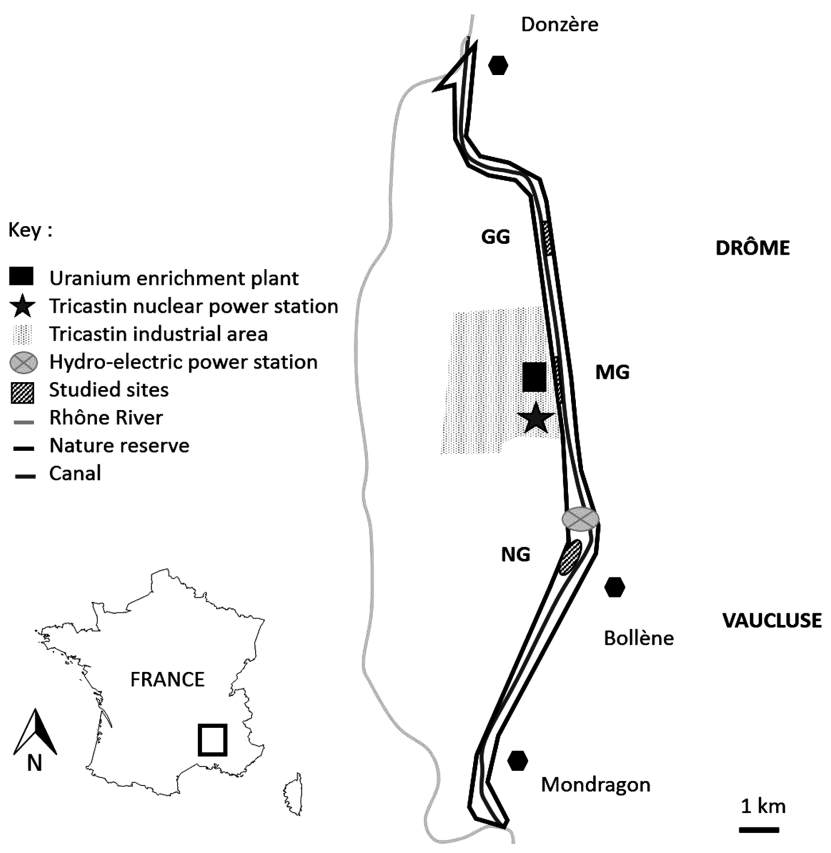

Fig. 1. Location of study site of Donzère-Mondragon in south-eastern France in the lower Rhône valley. Locations of study plots (striped black): grazed grassland (GG), mown grassland (MG) and non-grazed, non-mown grassland (NG), reserve limits (black), hydro-electric power station (light grey dot), canal (dark grey), and Rhône River (light grey). 
Table 1. Mean temperature $\left({ }^{\circ} \mathrm{C}\right)$ and total rainfall $(\mathrm{mm})$ at the study site during 2013-2014, 2014-2015, 2015-2016, over the last 30 years and during the spring seasons of 2014,2015 and 2016

\begin{tabular}{lcc}
\hline Period & Mean temperature $\left({ }^{\circ} \mathrm{C}\right)$ & Total rainfall $(\mathrm{mm})$ \\
\hline $2013-2014$ & 14.9 & 620.2 \\
$2014-2015$ & 14.8 & 828.0 \\
$2015-2016$ & 14.7 & 696.6 \\
Over 30 years & 14.0 & 700.9 \\
Spring 2014 & 13.9 & 76.8 \\
Spring 2015 & 14.1 & 113.2 \\
Spring 2016 & 12.7 & 122.9 \\
\hline
\end{tabular}

habitat diversity for flora and fauna (Roux et al. 2007). Between 1974 and 1981, a nuclear complex was developed on the right bank of the floodway (Fig. 1); its area is 600 ha and it is subject to some of the most stringent security constraints in France (Supplementary Appendix S1, available online).

In 2014, we selected three sites where three different types of management were applied: cattle grazing (GG); mechanical mowing (MG); and no domestic grazing or mowing (NG) (Fig. 1). Before 1999, no conservation management treatment was applied in the sites. As a consequence, all of these sites were covered by herbaceous plant communities dominated by a tussock grass (Brachypodium phoenicoides); shrubs (Crataegus monogyna, Rubus spp., etc.) have also naturally partially colonized these areas (Moinardeau et al. 2016).

The grazed grassland (GG) consists of 130 ha on the dykes of the supply channel and surrounded by electric fences. Management there began in 1999 with a herd of Galloway cattle (105 cows, 30 bulls and 40 calves) present from mid-November to mid-July (Fig. 1), which corresponds to a very low stocking rate of 0.50 livestock units (LU; $1 \mathrm{LU}=600 \mathrm{~kg} \mathrm{ha}^{-1} \mathrm{year}^{-1}$ ). Some ornamental trees were planted following the dyke construction (Roux et al. 2007).

The mown grassland (MG) consists of 4 ha situated on the same dyke as GG. It initially experienced the same grazing management, which was replaced by annual summer (August) mechanical mowing in 2012 because the immediate proximity of the nuclear complex suggested that mowing was a safer option (Fig. 1). After mowing, the herbaceous biomass remained in place on the site.

The control with no management (NG) was 1 ha and was also situated on the same dyke as GG and MG and had not been grazed or mown since 1954 (Fig. 1).

\section{Vegetation Monitoring}

We monitored herbaceous plants using 4- $\mathrm{m}^{2}$ quadrats, whose size was determined by calculation of minimum areas for each species, and we measured abundance and cover using Braun-Blanquet coefficients (Guinochet 1973). We also recorded vegetation height $(\mathrm{cm})$, total vegetation cover (\%) and bare soil cover (\%) of the quadrats. Plant nomenclature follows Tison et al. (2014).

We sampled the mown grassland (MG), an area of grassland grazed by cattle (GG) and the control without any management (NG). The quadrats were all more than $10 \mathrm{~m}$ apart; because the control area was too small, there were only five control quadrats.

We estimated alpha-diversity from the mean species richness per quadrat and beta-diversity by calculating the Bray-Curtis distance (Bray \& Curtis 1957) between the quadrats in each treatment and the mean Bray-Curtis distance between treatments. We also calculated the evenness indices (Pielou 1969). Botanical inventories were carried out in 2014, 2015 and 2016 during the May-June period, the peak of vegetation production.

\section{Soil Analyses}

Particle size, organic matter content and nutrient concentration were assessed. Percentages of clay $(<2 \mu \mathrm{m})$, silt $(2-50 \mu \mathrm{m})$ and sand $(50-2000 \mu \mathrm{m})$ were determined according to the Robinson method (Baize 2000). The soil $\mathrm{pH}$ and exchangeable $\mathrm{Ca}, \mathrm{K}$ and $\mathrm{P}_{2} \mathrm{O}_{5}$ were measured using the methods of Thomas (1996), Metson (1956) and Olsen et al. (1954). Organic C (Allison 1965) and total $\mathrm{N}$ contents (Bremner 1996) were quantified using a $\mathrm{CHN}$ elemental analyser (ISO 10694). For each treatment, five 200 -g soil samples were extracted at a depth of $0-10 \mathrm{~cm}$ in spring 2014. Soil samples were collected near each pair of the ten quadrats in the grazing and mowing treatments and near each of the five quadrats in the control.

Analyses were performed by the soil analysis laboratory at Institut National de la Recherche Agronomique in Arras (France).

\section{Aerial Photographic Analysis}

Multispectral photographs (red, green, blue and near-infrared) were taken by overflight of the reserve at $1050 \mathrm{~m}$. We chose a high resolution $(10 \mathrm{~cm})$ to limit impact from spatial heterogeneity on assessment of landscape variation (Garrigues 2004). Aerial surveys were realized during the second halves of May in 2014, 2015 and 2016. Images were orthorectified with hundreds of field reference points calibrated using centimetre-accurate differential GPS. The NDVI (Tucker 1979) was calculated with ArcGIS 10.2 (ESRI 2004); it reflects the vigour and density of vegetation (Purevdorj et al. 1998). The NDVI can be linked to vegetation biomass (Mafhoud 2009), especially in grazed sites probably containing photosynthetically active vegetation.

Dry herbaceous aboveground biomass weight was measured in May 2016 immediately after the aerial survey. Vegetation was clipped on 50 quadrats per site $(50 \times 50 \mathrm{~cm})$, oven dried at $50^{\circ} \mathrm{C}$ and weighed. The geographical coordinates of all the biomass quadrats were measured with the centimetre-accurate GPS (Trimble Geographic Positioning System receiver). The NDVIs of the biomass quadrats were extracted with a geographic information system (GIS). To be relevant biomass estimators, spectral indices must be able to differentiate vegetation from soil (Todd et al. 1998). On a second occasion, all the field points (geographical coordinates of the permanent plots) were referenced with centimetre-accurate GPS in order to compare field reality (species richness measured by botanical inventories in permanent quadrats) and the NDVI extracted from aerial photograph data. To extend our results to the site scale, the evenness of distribution of NDVI values between the two management techniques was tested.

\section{Statistical Analyses}

Vegetation composition was compared between treatments using non-metric multidimensional scaling (NMDS) based on BrayCurtis similarity (Borcard et al. 2011).

We ranked soil characteristics using principal component analysis (PCA) (Borcard et al. 2011). We compared effects of the different treatments on soil physicochemical parameters, soil particle sizes and nutrient contents via univariate analyses. 
To compare soil particle size, nutrient content and vegetation parameters, we used analysis of variance tests for multiple comparisons when the data were normally distributed (Shapiro-Wilk test) and when homogeneity of variances was respected (Bartlett test). This analysis was followed by post-hoc Tukey tests when a significant difference was detected among treatments. When data were not normal, we used Kruskal-Wallis tests for multiple comparisons, followed by pairwise Mann-Whitney-Wilcoxon tests, with the value of $p$ adjusted according to Benjamini and Hochberg (1995). Separate analyses of years were done to separate long-term effects of treatments (done 10-12 years ago for the GG and 3-5 years ago for the $M G$ ) from inter-annual variation due to changes of climatic conditions between years in the Mediterranean area (Caldeira et al. 2005). This climatic inter-annual variability will influence plant productivity and then grazing impacts on vegetation, although the herd of cattle has conserved the same number of animals during the survey.

To ensure that the NDVI was a good estimator at the overall scale of the managed sites, Spearman rank correlation tests were performed between NDVI values and herbaceous biomass weight values of each plot. Spearman rank correlations between NDVI and species richness obtained through the vegetation survey were realized for each plot. Correlations were then represented by linear regression. Evenness of distribution of NDVI values between grazed and mown plots was also calculated using an evenness formula at the scale of each site.

All statistical analyses were performed with $\mathrm{R}$ software version 2.15.3 (R Core Team 2012).

\section{Results}

\section{Plant Community Diversity and Structure}

In total, 179 plant species were recorded (Supplementary Table S1). The most common species were B. phoenicoides, Dactylis glomerata and Catapodium rigidum, which were found in more than $90 \%$ of the 75 quadrats inventoried during the 2014-2016 period. Thirty species were recorded in only one quadrat. Only one species is protected at the European community level under a European regulation (CE No. 338/97): Himantoglossum robertianum.

The NMDS analysis (stress $=0.13$ ) of the vegetation data discriminated three different herbaceous communities. The grassland grazed by cattle (GG) was dominated by short, annual plant species such as Galium parisiense and Alyssum alyssoides (Fig. 2). The mown grassland (MG) contained more perennial species such as D. glomerata and Carlina hispanica, along with short annuals such as Euphorbia exigua and Lysimachia linumstellatum. The control (NG) was essentially dominated by tall perennial species such as $B$. phoenicoides.

Some parameters had the same trends in 2014 as in 2015. The annual species frequency was higher for the mown treatment than for control (Table 2). Mean vegetation height was higher in control plots than MG and GG plots. Evenness was lower in control than in MG plots. Grazing had a significant impact on the dominant tussock perennial grass $B$. phoenicoides cover. Vegetation cover was higher in the MG treatment and control than in the GG treatment. In 2014, no significant difference was measured for species richness, whereas in 2015, species richness was higher in the MG and GG treatments than in the control.

Between 2014 and 2016, grazing had a higher impact on bare soil percentage than mowing or absence of management, whereas

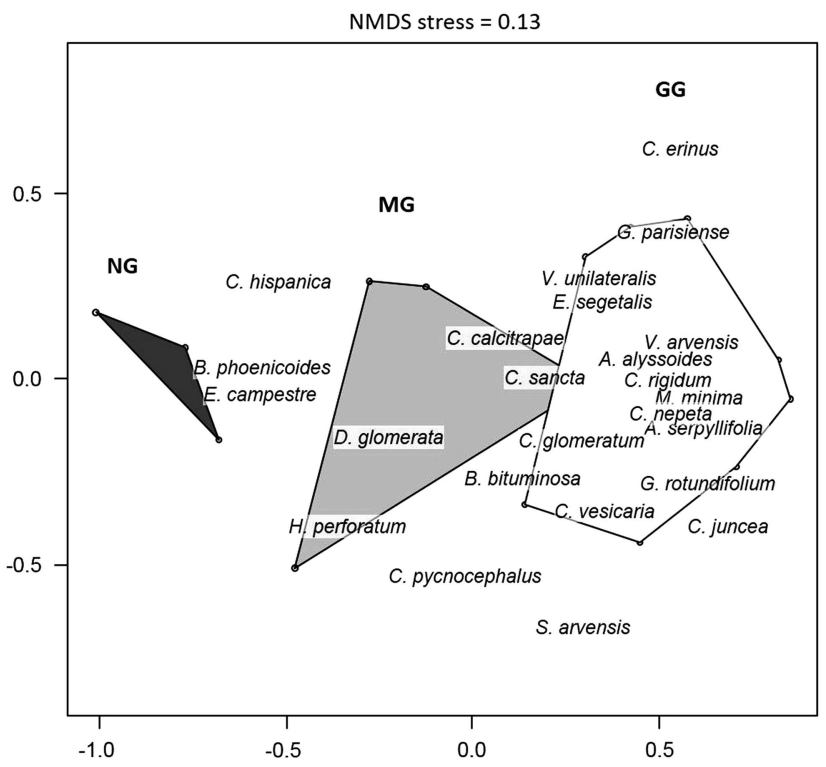

Fig. 2. Non-metric multidimensional scaling (NMDS) ordination (NMDS stress $=0.13$ ) based on 25 vegetation quadrat samples - ten in the grazed grassland (GG), ten in the mown grassland (MG) and five in the control without management (NG) realized in May 2016 in dykes of the canal of Donzère-Mondragon in the Lower Rhône valley, south-eastern France. Polygons represent treatments; only the plant species most correlated to the two first axes are indicated ( $p=0.01$ for both axes).

no difference was found between mowing and absence of management.

Significant differences in Bray-Curtis indices among the three treatments from 2014 to 2016 indicated a greater heterogeneity of vegetation in the GG treatment than in the MG treatment and the control. The Bray-Curtis index was also higher for the $\mathrm{MG}$ treatment than for control (Table 2).

In 2016, evenness was greater in the GG treatment than in the MG treatment, which was also greater than in the control. Species richness was higher in the MG and GG treatments than in control (Table 2). In 2016, vegetation cover and mean vegetation height were significantly lower in the GG and MG treatments than in control (Table 2). No significant difference was found between the GG and MG plots in annual species frequency (Table 2). Grazing also had a significant impact on the dominant tussock perennial grass $B$. phoenicoides cover, which was significantly lower in the GG.

\section{Soil Characteristics}

Axis 1 of the PCA (50.99\%) opposed the managed sites, the MG and the GG treatments, to the control (NG) (Fig. 3). On this axis, mown and grazed grasslands were correlated with higher coarse sand and organic matter contents (C and N). Axis $2(25.60 \%)$ expressed some heterogeneity of coarse sand content in the soil of the GG treatment.

The univariate analyses showed the MG samples had significantly lower fine silt, $\mathrm{CaCO}_{3}$ and $\mathrm{P}_{2} \mathrm{O}_{5}$ contents than the control. $\mathrm{pH}$ was more basic in control than in the two managed treatments. Coarse sand content was significantly higher in the GG and MG treatments than in control. MG samples had significantly more clay and coarse silt contents than GG treatments. No significant difference in clay content was detected between the MG treatment and control plots. The control had a significantly higher fine silt content than the two other treatments. No significant differences were found for the other soil parameters among the three treatments (Supplementary Table S2). 
Table 2. Results of vegetation analyses in the cattle grazed grassland (GG), mown grassland (MG) and control (NG) on dykes of the Donzère-Mondragon canal in the Lower Rhône valley during 2014-2016. Two values in the same row with a different letter are significantly different (Tukey post-hoc or Mann-Whitney-Wilcoxon tests). ${ }^{\star} p<0.05,{ }^{\star \star} p<0.01,{ }^{\star \star \star} p<0.001$

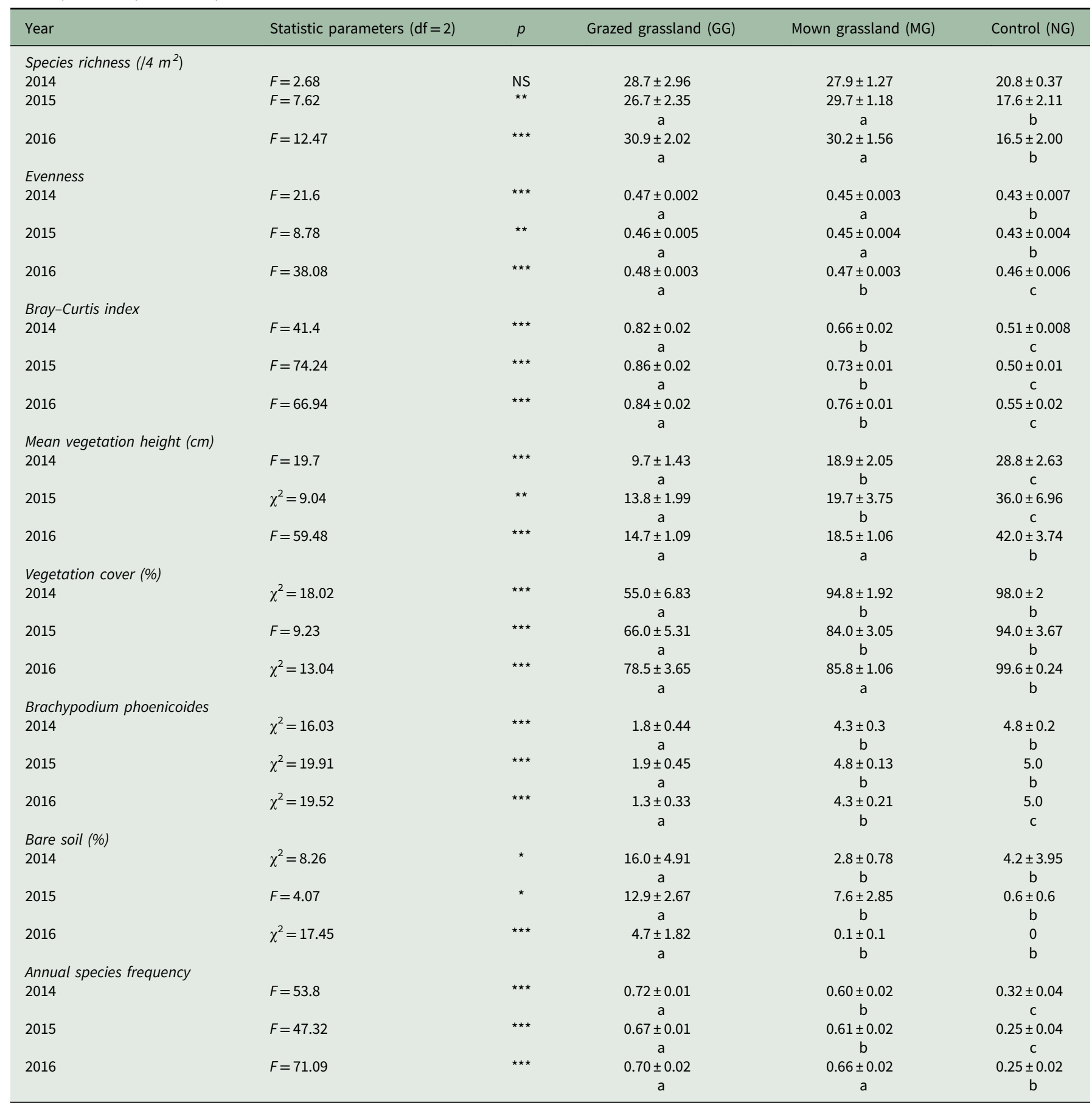

\section{Vegetation Indices}

There was a significant linear regression between biomass and the NDVI values for both treatments (Supplementary Fig. S1). The correlation was greater for the MG treatment (rho $=0.74$, $p<0.001$ ) than for the GG treatment (rho $=0.58, p<0.01$ ), but the statistical significance was greater for the latter.

The NDVI and plant species richness were also negatively correlated for the grazed treatment between 2014 and 2016 $(p<0.05)$. In 2014, this coefficient was medium (rho $=-0.37$ ), but was higher in 2015 and 2016 (rho $=-0.5$ and -0.58 , respectively; $p<0.05$ ) (Supplementary Fig. S2).

The different NDVI values for treatments GG and MG showed greater evenness of distribution for the grazing treatment $(0.35 \pm 0.01)$ than for the mowing treatment $(0.30 \pm 0.01 ; t=-3.42$, $\mathrm{df}=3.98, p<0.05$ ) (Supplementary Fig. S3). This trend was also observed from maps (Supplementary Appendix S2) representing NDVI values ranked in ten classes each for GG and MG treatment and for each study year. Classes 1-5 showed the lowest NDVI values and classes 6-10 showed the highest NDVI values. 


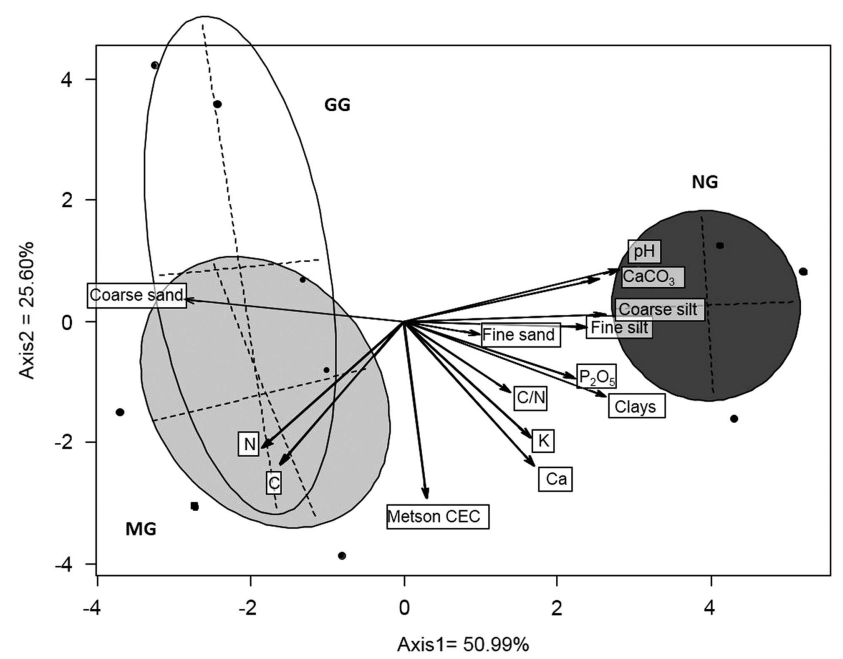

Fig. 3. Principal component analysis ordination based on the 15 soil samples analysed in the cattle-grazed grassland (GG, open), mown grassland (MG, light grey) and control grassland (NG, dark grey) along the Donzère-Mondragon canal in the Lower Rhône valley. Arrows represent soil variables: chemical content $\left(\mathrm{K}, \mathrm{P}, \mathrm{CaCO}_{3}\right.$, $\mathrm{pH}$, organic $\mathrm{C}$, total $\mathrm{N}, \mathrm{C} / \mathrm{N}$, Metson cation exchange capacity (CEC)) and particle sizes (clay $(<0.002 \mathrm{~mm})$, fine silt $(0.002-0.020 \mathrm{~mm})$, coarse silt $(0.2-2.0 \mathrm{~mm})$, fine sand $(0.05-0.20 \mathrm{~mm})$ and coarse sand $(0.2-2.0 \mathrm{~mm}))$.

\section{Discussion}

\section{Impacts of the Different Conservation Management Treatments}

After three years of monitoring, cattle grazing at a low stocking density appeared to be a more effective way to enhance plant community diversity than mowing at a rate of 1 cut year $^{-1}$ or the absence of domestic grazing. Grazing lowered vegetation cover and height and the competitive ability of perennial grasses (Stephens \& Krebs 1986), here B. phoenicoides. It increased the proportion of bare soil, favouring the establishment of lowcompetitive species, mainly short, annual species (Hayes \& Holl 2003). Evenness was significantly higher in the grazed treatment in 2016. This result is in accordance with results already obtained from previous studies that also reported an increase of evenness after re-establishment of low-density grazing in grasslands with a homogeneous vegetation structure, due to the dominance of perennial tussock grasses (Tälle et al. 2016). Some annual species are recorded as rare or very rare species of the Vaucluse département (Girerd 1991), such as Alyssum simplex or Anisantha lanceolatus.

Cattle grazing increased the heterogeneity of plant communities more than mowing, as revealed by Bray-Curtis indices. This may be the result of the Galloway cow trampling: these heavy herbivores could induce erosion of the finest particles at the soil surface (Mulholland \& Fullen 1991). The absence of domestic grazing leads to a lower heterogeneity of plant communities and to the development of tall, perennial tussock grasses, especially B. phoenicoides, which covered at least $75 \%$ of the soil over the 2014-2016 period. No statistical difference was found in organic matter among the three treatments. The highest organic matter content may occur in ungrazed soil, which can be attributed to the accumulation of biomass and litter that are usually removed by herbivores in grazed grasslands (Sigcha et al. 2018) and in mown grasslands when hay is removed. In our case, the hay was left behind.
The NDVI was a good estimator of aboveground herbaceous biomass for the two managed sites here (Jensen 2007). Yet we found significant correlations between vegetation index values and plant species richness of quadrats from the grazing treatment. The high resolution of our aerial photographs $(10 \mathrm{~cm})$ therefore allowed us to clearly link the results of field studies with remote sensing data. Results from aerial photographs and vegetation surveys followed the same trend: the higher and denser the vegetation patch, the lower the species richness. Thus, generalizing these results to the entire grazed site allows us to make sitescale recommendations for conservation management.

\section{Implications for the Restoration and Management of Dyke Vegetation}

Over a short time period (2014-2016), the low stocking density not only led to greater structural heterogeneity of short grasslands than without domestic grazing, but also to higher species richness and evenness than with mowing. The proportion of rare short, annual species increased after the implementation of low-density grazing. Nonetheless, the low-density cattle grazing initiated in 1999, and considered unsuitable for safety reasons, was replaced by mowing at the rate of 1 cut year $^{-1}$ in 2012 . Our results demonstrate that replacing grazing by mechanical mowing was not the best choice in terms of nature conservation, leading to a significant decrease in beta-diversity and poorer control of B. phoenicoides.

Several studies emphasized the relevance of satellite data in ecological studies (Turner et al. 2003) and the advantages of the complementary use of remote sensing, aerial photographs and traditional methods to monitor vegetation, whether for agronomic or conservation purposes (Flynn 2006). Joint use of aerial photographs and of the NDVI appears particularly relevant for analysing the impacts of management at the site scale (Pettorelli et al. 2005a). Here, cattle grazing was shown to be the best option for conservation, leading to the lowest NDVI values (lower biomass, lower density and leaf cover) and thus to higher species richness.

Our study adds to the evidence of how extensive grazing can help manage biodiversity on semi-natural and non-agricultural land (e.g. van Wieren \& Bakker 1998, Carboni et al. 2015). Nevertheless, the success of grazing management will depend on the grazing pressure and period of application chosen. It will also depend on how well the person in charge of the herd applies the prescribed management. This may in turn be affected by technical and socioeconomic conditions, in addition to purely environmental or agronomic issues. At the dyke of Donzère-Mondragon, the same breeder has owned the herd since 1999 under a multiyear contract guaranteeing him a sustainable and durable livelihood and optimal conditions to manage his flock.

Supplementary Material. For supplementary material accompanying this paper, visit www.cambridge.org/core/journals/environmental-conservation

Acknowledgements. Our thanks to Romain Brusson (CNR) and to Denis Roux (ONCFS) for facilitating access to the sites. We gratefully acknowledge the technical assistance with botanical inventories and grazing surveys received from Daniel Pavon, Loïc Willm, Alain Sandoz, Julie Chenot, Anne Aurière, Christel Vidaller, Arthur Rocher, Bénédicte Beylier, Laurent Garde, Bruna Romanini and Jean-Noël Laffite. We thank Marjorie Sweetko for English language revision. Finally, we thank the two anonymous reviewers for their useful comments. 
Financial Support. We are grateful to the Compagnie Nationale du Rhône (CNR), the owner of the site and the Office National de la Chasse et de la Faune Sauvage (ONCFS), the site manager, for their financial support. We also thank SFR Tersys for the grant awarded in 2014.

\section{References}

Allison LE (1965) Organic carbon. In: Methods of Soil Analysis, Part 2, ed. CABlack, pp. 1367-1378. Madison, WI, USA: ASA.

Baize D (2000) Guide des Analyses en Pédologie. Paris, France: INRA.

Barradas I, Cohen JE (1994) Disturbances allow coexistence of competing species. Journal of Mathematical Biology 32: 663-676.

Benjamini Y, Hochberg Y (1995) Controlling the false discovery rate: a practical and powerful approach to multiple testing. Journal of the Royal Statistical Society 57: 289-300.

Borcard D, Gillet F, Legendre P (2011) Numerical Ecology with R. New York, NY, USA: Springer.

Bray JR, Curtis JT (1957) An ordination of upland forest communities of southern Wisconsin. Ecological Monographs 27: 325-349.

Bremner JM (1996) Nitrogen total. In: Methods of Soil Analysis. Part 3 Chemical Methods, Soil Science Society of America Book Series, 5, eds. DL Sparks, AL Page, PA Helmke, RH Loeppert, PN Soltanpour and MATabatabai, et al., pp. 1085-1121. Madison, WI, USA: Soil Science Society of America, American Society of Agronomy.

Caldeira MC, Hector A, Loreau M, Pereira JS (2005) Species richness, temporal variability and resistance of biomass production in a Mediterranean grassland. Oikos 110: 115-123.

Carboni M, Dengler J, Mantilla-Contreras J, Venn S, Török P (2015) Conservation value, management and restoration of Europe's semi-natural open landscapes. Hacquetia 14: 5-17.

Collins SL, Knapp AK, Briggs JM, Blair JM, Steinauer EM (1998) Modulation of diversity by grazing and mowing in native tallgrass prairie. Science 280 : 745-747.

Cousens R, Dytham C, Law R (2008) Dispersal in Plants: A Population Perspective. Oxford, UK: Oxford University Press.

Duncan P (1992) Horses and Grasses: The Nutritional Ecology of Equids and Their Impact on the Camargue. New York, NY, USA: Springer Verlag.

ESRI (2004) ArcGIS Desktop: Release 10. Redlands, CA: Environmental Systems Research Institute.

Eversham BC, Roy DB, Telfer MG (1996) Urban, industrial and other manmade sites as analogues of natural habitats for Carabidae. Annales Zoologici Fennici 33: 149-156.

Firn J, House APN, Buckley YM (2010) Alternative states models provide an effective framework for invasive species control and restoration of native communities. Journal of Applied Ecology 47: 96-105.

Flynn ES (2006) Using NDVI as a Pasture Management Tool. Master's thesis. Lexington, KY, USA: University of Kentucky.

Garrigues S (2004) Hétérogénéité Spatiale des Surfaces Terrestres en Télédétection: Caractérisation et Influence sur l'Estimation des Variables Biophysiques. Rennes, France: Agrocampus - École nationale supérieure d'agronomie de Rennes.

Girerd B (1991) La Flore du Département de Vaucluse. Avignon, France: Editions Alain Barthélémy.

Grumbine RE (1997) Reflections on 'What is ecosystem management?' Conservation Biology 11(1): 41-47.

Guinochet M (1973) Phytosociologie. Paris, France: Masson.

Hautier Y, Niklaus PA, Hector A (2009) Competition for light causes plant biodiversity loss after eutrophication. Science 324(5927): 636-638.

Hayes GF, Holl KD (2003) Cattle grazing impacts on annual forbs and vegetation composition of mesic grasslands in California. Conservation Biology 17(6): 1694-1702.

Hobbs RJ, Arico S, Aronson J, Baron JS, Bridgewater P, Cramer VA et al. (2006) Novel ecosystems: theoretical and management aspects of the new ecological world order. Global Ecology and Biogeography 15: 1-7.
Hobbs RJ, Higgs ES, Hall CM (2013) Novel Ecosystems: Intervening in the New Ecological World Order. Hoboken, NJ, USA: Wiley-Blackwell.

Jensen K, Trepel M, Merritt D, Rosenthal G (2006) Restoration ecology of river valleys. Basic and Applied Ecology 7: 383-387.

Jensen RR, Hardin PJ (2007) Using satellite data to estimate urban leaf area index. In: Geo-Spatial Technologies in Urban Environments, eds. RR Jensen, JD Gatrell and D McLean, pp. 93-107. Berlin, Germany: Springer Berlin Heidelberg.

Kowarik I (2011) Novel urban ecosystems, biodiversity, and conservation. Environmental Pollution 159: 1974-1983.

Mafhoud I (2009) Cartographie et Mesure de la Biodiversité du Mont Ventoux. Approche par Système d'Information Géographique et Télédétection, Préconisations Méthodologiques et Application pour l'Aménagement Forestier. Avignon, France: University of Avignon.

Marriot CA, Hood K, Fischer JM, Pakeman RJ (2009) Long-term impacts of extensive grazing and abandonment on the species composition, richness, diversity and productivity of agricultural grassland. Agriculture, Ecosystems \& Environment 134: 190-200.

Metson AJ (1956) Methods of Chemical Analysis for Soil Survey Samples. Wellington, New Zealand: New Zealand Department of Scientific and Industrial Research.

Middleton BA, Holsten B, van Diggelen R. (2006) Biodiversity management of fens and fen meadows by grazing, cutting and burning. Applied Vegetation Science 9: 307-316.

Moinardeau C, Mesléard F, Dutoit T (2016) Using different grazing practices for increasing plant biodiversity in the dykes and embankments along the Rhone river (Southern France). Environmental Management 58: 984-997.

Mulholland B, Fullen MA (1991) Cattle trampling and soil compaction on loamy sands. Soil Use and Management 7(4): 189-193.

Olsen SR, Cole CV, Watanabe FS, Dean LA (1954) Estimation of Available Phosphorus in Soils by Extraction with Sodium Bicarbonate. Washington, DC, USA: US Department of Agriculture.

Pettorelli N, Vik JO, Mysterud A, Gaillard JM, Tucker CJ, Stenseth NC (2005a) Using the satellite-derived NDVI to assess ecological responses to environmental change. Trends in Ecology and Evolution 20(9): 504-510.

Pettorelli N, Ryan S, Mueller T, Bunnefeld N, Bogumiła J, Lima M, Kausrud K (2011) The Normalized Difference Vegetation Index (NDVI): unforeseen successes in animal ecology. Climate Research 46: 15-27.

Pielou EC (1969) An Introduction to Mathematical Ecology. New York, NY, USA: Wiley-Interscience.

Poschlod P, Wallis De Vries MF (2002) The historical and socioeconomic perspective of calcareous grasslands - lessons from the distant and recent past. Biological Conservation 104: 361-376.

Purevdorj TS, Tateishi R, Ishiyama T, Honda Y (1998) Relationships between percent vegetation cover and vegetation indices. International Journal of Remote Sensing 19(18): 3519-3535.

R Core Team (2012) R: A Language and Environment for Statistical Computing. Vienna, Austria: R Foundation for Statistical Computing.

Rosenthal G, Schrautzer J, Eichberg C (2012) Low-intensity grazing with domestic herbivores: a tool for maintaining and restoring plant diversity in temperate Europe. Tuexenia 32: 167-205.

Roux D, Roux JP, Debiesse L (2007) Donzère-Mondragon: La Nature aux Portes de l'Urbain... Paris, France: Office National de la Chasse et de la Faune Sauvage.

Stephens DW, Krebs JR (1986) Foraging Theory. Princeton, NJ, USA: Princeton University Press.

Tälle M, Deák B, Poschlod P, Valkó O, Westerberg L, Milberg P (2016) Grazing vs. mowing: a meta-analysis of biodiversity benefits for grassland management. Agriculture, Ecosystems and Environment 222: 200-212.

Tälle M (2018) Conservation of Semi-Natural Grasslands: Effects of Different Management Methods on Biodiversity. Linköping, Sweden: Linköping University Electronic Press.

Thomas GW (1996) Soil pH and soil acidity. In: Methods of Soil Analysis. Part 3 - Chemical Methods, Soil Science Society of America Book Series 5, eds. DL Sparks, AL Page, PA Helmke, RH Loeppert, PN Soltanpour and MA Tabatabai, et al., pp. 475-490. Madison, WI, USA: Soil Science Society of America, American Society of Agronomy.

Tison JM, Jauzein P, Michaud H (2014) Flore de la France Méditerranéenne Continentale. Turriers, France: Naturalia Publications. 
Todd SW, Hoffer RM, Milchunas DG (1998) Biomass estimation on grazed and ungrazed rangelands using spectral indices. International Journal of Remote Sensing 19: 427-438.

Tucker CJ (1979) Red and photographic infrared linear combination for monitoring vegetation. Remote Sensing of Environment 8: 127-150.

Turner W, Spector S, Gardiner N, Fladeland M, Sterling E, Steininger M (2003) Remote sensing for biodiversity science and conservation. Trends in Ecology and Evolution 18(6): 306-314.

Van Diggelen R, Middleton B, Bakker J, Grootjans AP, Wassen M (2006) Fens and floodplains of the temperate zone: present status, threats, conservation and restoration. Applied Vegetation Science 9: 157-162.
Van Wieren SE, Bakker JP (1998) Grazing for conservation in the 21st century. In: Grazing and Conservation Management. Conservation Biology Series 11, eds. MFWallis De Vries, JPBakker and SEVan Weiren, pp. 349-363. Dordrecht, The Netherlands: Kluwer Academic.

Wallis De Vries MF, Parkinson AE, Dulphy JP, Sayer M, Diana E (2007) Effects of livestock breed and grazing intensity on biodiversity and production in grazing systems. 4. Effects on animal diversity. Grass and Forage Science 62(2): 185-197.

Weiss SB (1999) Cars, cows, and checkerspot butterflies: nitrogen deposition and management of nutrient-poor grasslands for a threatened species. Conservation Biology 13(6): 1476-1486. 